\title{
PEMBELAJARAN NILAI MULTIKULTURAL DALAM BUDAYA MADRASAH DI MIN I KOTA MALANG
}

\author{
Fita Mustafida*, Yaqub Cikusin** \\ Program Doktor PAI Multikultural \\ Pascasarjana Universitas Islam Malang (UNISMA)
}

Email : fitamustafida@unisma.ac.id

\begin{abstract}
Abstrak
Tujuan penelitian ini adalah untuk mendeskripsikan, menganalisis, dan menginterpretasi terhadap konsep dan implementasi proses pembelajaran nilai multikultural dalam budaya madrasah di Madrasah Ibtidaiyah Negeri (MIN) I Kota Malang. Pendekatan yang digunakan adalah kualitatif dengan jenis etnografi. Pengumpulan data dilakukan melalui observasi partisipan, wawancara mendalam, dan analisis dokumen. Sementara tehnik analisis data mengacu pada model Spredly. Yakni melalui; a) analisis domain, b) taksonomi, c) komponensial dan d) analisis tema budaya. Hasil penelitian menunjukkan bahwa proses pembelajaran nilai dan sikap multikultural di MIN I Kota Malang dilakukan melalui pembiasaan, dan program kegiatan yang terintegrasi dalam budaya madrasah yakni budaya beriman, berakhlak mulia dan berprestasi.
\end{abstract}

Kata kunci: pembelajaran, nilai multikultural, budaya madrasah

\section{Abstract}

The purpose of this study was to describe, analyze, and interpret the concepts and implementation of the process of learning multicultural values in madrasah culture in Madrasah Ibtidaiyah Negeri (MIN) I Malang City. The approach used is qualitative with ethnographic types. Data collection is done through participant observation, in-depth interviews, and document analysis. While the data analysis technique refers to the Spredly model. Namely through; a) domain analysis, b) taxonomy, c) components and d) analysis of cultural themes. The results showed that the learning process of multicultural values and attitudes in MIN I Malang City was carried out through habituation, and an integrated program of activities in the culture of the madrasa namely a culture of faith, noble character and achievement. Keywords: learning, multicultural value, madrasah culture 


\section{PENDAHULUAN}

Pendidikan multikultural dipandang sebagai salah satu alternatif model pendidikan yang paling cocok untuk menanamkan nilai-nilai multikultural pada peserta didik dalam konteks negara Indonesia dengan tingkat heterogenitas yang tinggi. Saat ini, konsep pendidikan multikultural mulai menuai popularitas di kalangan pemerhati pendidikan dan penyusun kebijakan pendidikan yang mengharapkan adanya pengembangan fokus terhadap pendidikan nilai yang memberikan penghargaan dan penghormatan terhadap hak-hak warga negara tanpa membeda-bedakan etnis, agama, ras, budaya dan warna kulit seiring dengan maraknya konflik radikalisme, isu sara dan berbagai ketegangan yang terjadi beberapa tahun belakangan ini.

MIN I Kota Malang merupakan salah satu lembaga pendidikan yang merespon positif terhadap kebijakan pendidikan multikultural melalui kurikulum 2013 yang menjadi pedoman penyelenggaraan pendidikan saat ini. Meski secara legal formal MIN I Kota Malang tidak menobatkan diri sebagai sekolah multikultural, tetapi telah membuktikan adanya konsep dan implementasi pendidikan multikultural melalui aktivitas dan kegiatan madrasah yang berupaya untuk mendidikkan nilai-nilai yang terkadung dalam ideologi multikulturalisme ke dalam kegiatan pembelajaran. Hal tersebut dibuktikan dengan adanya nilai-nilai pendidikan multikultural yang diadobsi dan diadabtasikan ke dalam aktivitas belajar dan bermasyarakat, melalui hubungan dan interaksi warga madrasah yang mampu mengelola keragaman warga madrasah dengan sikap menerima perbedaan sehingga dapat hidup bersama di lingkungan sekolah dengan harmonis.

Atas dasar tersebut, maka MIN I Kota Malang dianggap layak dijadikan lokus penelitian tentang pembelajaran nilai Multikultural khususnya pada budaya madrasah yang dikembangkan. Hal tersebut dikarenakan pertama, pada lokus tersebut ditemukan penghormatan dan pengakuan terhadap keragaman dan kesederajatan pedagogis melalui pengenalan dan penanaman nilai-nilai pendidikan multikultural baik di dalam maupun di luar kelas apapun etnik, status sosial, dan jenis kelaminnya. Kedua, ada indikasi proses pembelajaran nilai dan sikap multikultural melalui kultur Madrasah yang dibangun.

Fokus penelitian ini adalah untuk menghgkaji tentang: 1) Nilai Multikultural Apa Saja yang Tumbuh dalam Budaya Madrasah di MIN I Kota Malang?, 2) Bagaimana Proses Pembelajaran Nilai Multikultural Melalui Budaya Madrasah di MIN I Kota Malang?. Sedangkan tujuan penelitian ini secara umum untuk mendeskripsikan, menganalisis, dan menginterpretasi terhadap konsep dan implementasi proses pembelajaran 
nilai multikultural dalam budaya madrasah di Madrasah Ibtidaiyah Negeri (MIN) I Kota Malang.

Hasil penelitian ini dapat memberi kontribusi akademis bagi pengembangan Model Pembelajaran Pendidikan Agama Islam yang berarti bagi;

1. Guru, yaitu memberikan nuansa baru dalam melakukan inovasi model pembelajaran Pendidikan Agama Islam yang berparadigma multikultural dalam mendorong terciptanya sikap multikulturalis (humanis-pluralis-dan inklusif) demi menuju kehidupan yang harmoni

2. Bagi peserta didik dapat membantu dalam membangun pemahaman dan mengembangkan prilaku yang positif terhadap perbedaan kultural

3. Menjadi bahan pertimbangan atau masukan bagi pimpinan lembaga pendidikan (kepala madrasah), guru, komite dan stakeholder lainnya untuk mengembangkan Pembelajaran Pendidikan Agama Islam Multikultural khususnya di Madrasah Ibtidaiyah

4. Peneliti selanjutnya dapat dijadikan sebagai bahan pertimbangan atau rujukan dalam bidang atau fokus yang sama. Serta memberikan kerangka solusi terhadap masalah atau fokus yang serupa.

\section{METODE}

Metode dalam rancangan penelitian ini lebih pada penegasan yang merujuk pada prosedur-prosedur umum kemetodean yang akan digunakan. Diantaranya: pendekatan dan jenis penelitian, lokasi, subjek dan informan penelitian, kehadiran peneliti, teknik pengumpulan dan analisis data, pengecekan keabsahan data, serta tahap-tahap penelitian. Penelitian kualitatif digunakan karena esensi dari penelitian ini adalah untuk memahami secara mendalam proses dan makna peristiwa dalam lingkungan sosial budaya. Jenis etnografi dikehendaki karena memungkinkan dan membuka peluang bagi peneliti untuk mengkaji praktek pendidikan multikultural di MIN I Kota Malang secara mendalam, menyeluruh, dan terperinci mengingat pendidikan sebagai sebuah kegiatan yang memiliki kompleksitas yang tinggi. Selain itu, etnografi juga dapat "merekam" secara terperinci dan apa adanya proses pembelajaran lengkap dengan segala permasalahan, kelebihan dan kekurangannya.

Kehadiran peneliti dalam penelitian tentang pembelajaran nilai-nilai multikultural melalui budaya madrasah di MIN I Kota Malang adalah mutlak, karena dalam penelitian kualitatif peneliti adalah instrumen kunci 
yang berperan serta dalam penelitian. ${ }^{1}$ Namun, meskipun peneliti sebagai instrumen kunci, tetapi perlu dibantu oleh alat-alat yang lain seperti recorder, camera, buku catatan, bolpoin dll. Sesuai dengan yang diungkapkan oleh Sugiono bahwa selain sebagai instrumen kunci peneliti kualitatif juga dibantu dengan alat yang lain untuk mendukung kegiatan penelitian. Yakni pedoman wawancara, pedoman observasi, alat tulis, buku catatan, dan alat - alat yang digunakan dalam mendokumentasikan penelitian, seperti recorder, kamera dan sebagainya. ${ }^{2}$

\section{PEMBAHASAN}

\section{Nilai Multikultural yang Tumbuh dalam Budaya Madrasah di MIN I Kota Malang}

Nilai, merupakan suatu keyakinan dan kepercayaan yang menjadi dasar bagi seseorang atau sekelompok orang untuk memilih bertindak. ${ }^{3}$ Hasil identifikasi terhadap nilai-nilai Islam multikultural yang tumbuh dalam budaya Madrasah di MIN I Kota Malang, menghasilkan sebuah kesimpulan bahwa MIN I Kota Malang telah mengajarkan dan mendidikkan nilai-nilai Islam multikultural. Pernyataan tersebut, dibuktikan dengan adanya muatan nilai-nilai Islam multikultural dalam budaya madrasah yang yang tercerminkan dari artifak (material culture) dan aktivitas kultur (behavioral culture). Aspek material culture dapat ditangkap melalui halhal yang dapat diamati yakni simbol-simbol atau slogan yang ada di Madrasah. Diantaranya visi dan misi madrasah, slogan "tiada hari tanpa prestasi", pajangan yang menuliskan norma-norma etika, seperti $5 \mathrm{~S}$ (senyum, sapa, salam, salim, dan santu), 5K (keamanan, kebersihan, ketertiban, keindahan, dan kekeluargaan), 5T (tertib waktu, tertib administrasi, tertib belajar, tertib mengajar, tertib lingkungan), yang dipajang pada ruang tamu, kantor, dan di ruang kelas, termasuk berbagai pajangan sekolah yang menggambarkan nilai-nilai multikultural yakni adalah pajangan etalase besar yang berisi piala dan medali penghargaan sekolah. Sedangkan aspek behavior tercermin dari aktivitas kehidupan madrasah, interaksi siswa, guru, karyawan, bahkan orang tua/wali murid

\footnotetext{
${ }^{1}$ W. John Creswell, 2015. Penelitian Kualitatif dan Desain Riset: Memilih diantara Lima Pendekatan, (Yogyakarta. Pustaka Pelajar, 2015), 108. 2011), 6 .

${ }^{2}$ Sugiono, Metode Penelitian Kuantitatif Kualitatif dan $R \& D$, (Bandung: Alfabeta,

${ }^{3}$ Muhaimin, Nuansa Baru Pendidikan Islam. (Jakarta: PT. Grafindo Persada, 2006), 148.
} 
merupakan contoh paling sederhana yang mencerminkan adanya implementasi nilai multikultural di MIN I Kota Malang.

Berdasarkan hasil temuan tentang nilai-nilai pendidikan Islam multikultural yang tumbuh melalui budaya madrasah di MIN I Kota Malang dapat ditemukan kurang lebih ada 12 nilai. Diantara nilai tersebut adalah: 1) Nilai keberagamaan berupa Keimanan terhadap Tuhan Yang Maha Esa, 2) Keramahan dan Sopan Santun, 3) Toleransi, 4) Kesetaraan, 5) Keadilan, 6) Humanis, 7) Tolong menolong, 8) Kebangsaan, 9) Kebersamaan, 10) Kekeluargaan, 11) Kesalehan sosial, dan 12) Penghargaan terhadap prestasi. 1) Nilai keberagamaan berupa Keimanan terhadap Tuhan Yang Maha Esa,

Implementasi nilai keimanan di MIN I Kota Malang diwujudkan dalam bentuk budaya relegius yang tercermin dalam kehidupan sehari-hari melalui program ritual keagamaan wajib dan reguler. Diantaranya; 1) Pembiasaan shalat tepat waktu dan pembiasaan shalat dhuha dan dhuhur berjamaah, 2) Gemar membaca al-quran, yang dikembangkan melalui kegiatan hafalan surat-surat pendek, membaca surat pendek dengan tartil sebelum shalat jamaah dhuha dan dhuhur, kelas tahfidz, dan tradisi khotmil qur'an, serta pembiasaan tiada hari tanpa membaca al-qur'an. 3) Pembiasaan amal ibadah sunnah (puasa sunnah di hari senin dan kamis), sholat tahajud, berdzikir dan mendoakan orang tua. Selain ketiga budaya relegius di atas, nilai keimanan ini juga tercermin dari kebersihan dan keindahan lingkungan fisik-material MIN I Kota Malang.

Ulasan di atas, menunjukkan bahwa MIN I Kota Malang telah berupaya mengembangkan pendidikan berbasis nilai-nilai Islam. Asumsi ini didasarkan pada telaah praktek pendidikan yang dikembangkan dan dijabarkan atas dasar ketuhanan (ilahiyah) secara utuh, integratif, komprehensif dan interaktif (Buchari, 1994). ${ }^{4}$

Berkembangnya nilai keimanan di MIN I Kota Malang sejalan dengan esensi pembelajaran agama pada tingkat Madrasah Ibtidaiyah (MI), yakni berupaya menanamkan jiwa ketauhidan, sehingga kompetensi lulusan Madrasah Ibtidaiyah memiliki kualitas keimanan yang baik. ${ }^{5}$

2) Keramahan dan Sopan Santun

Keramahan dan sopan santun merupakan nilai budaya dan karakter bangsa Indonesia yang menjunjung tinggi nilai-nilai persaudaraan/ukhuwah.

${ }^{4}$ Hujair AH Sanaky, Mengembangkan Model Ideal Pendidikan Islami. ELTARBAWI VOL. 7 NO.1 2014, 2.

5 Ngainun Naim dan Ahmad Syauqi, Pendidikan Multikultural: Konsep dan Aplikasi (Jogjakarta: Ar-Ruzz Media, 2008), 206. 
Zuriah, ${ }^{6}$ mengatakan bahwa sopan santun merupakan tata cara atau aturan turun temurun yang berkembang dalam budaya masyarakat agar terjalin hubungan yang akrab, saling pengertian, hormat menghormati menurut adat yang telah ditentukan. Keduanya merupakan sikap yang dicintai oleh Allah, orang yang ramah, lemah lembut, baik budi bahasa, dan manis tutur katanya akan selalu diterima dalam pergaulan. Sebagaimana firman Allah (QS. Ali Imran: 159).

"Maka disebabkan rahmat dari Allah lah kamu berlaku lemah lembut terhadap mereka, sekiranya kamu bersikap keras lagi berhati kasar, tentulah mereka menjauhkan diri dari sekelilingmu."

3) Nilai Toleransi

Zuhairi Misrawi ${ }^{7}$ memahami toleransi sebagai sikap saling menghargai, menghormati keragaman budaya dan perbedaan kebebasan berekspresi, termasuk dalam berkeyakinan. Dalam Islam, Nabi Muhammad Saw. merupakan teladan yang baik dalam mengimplementasikan pendidikan toleransi yang merangkul semua etnis, agama tanpa membedakan warna kulit dan suku bangsa. Secara historis perkawinan Nabi Muhammad Saw. Dengan istri-istri yang berbeda etnis, dan latar belakang agama dan status sosial merupakan sebuah realitas pendidikan nilai multikultural, yakni toleransi. Sebut saja Shofiyah (wanita mulia yang beragama Yahudi) sebelum dinikahi Rasulullah, Maria bin Sam'un (yang berbangsa Koptik dari Mesir) yang juga merupakan seorang budak tawanan perang. Teman-teman bergaul Nabi yang tidak melihat perbedaan status, seperti Bilal Bin Rabah (budak berkulit hitam), Salman al Farizi (berbangsa Persi) dan masih banyak lagi contoh pergaulan nabi yang menggambarkan pendidikan toleransi yang dilakukan.

Fakta ini menunjukkan bahwa agama Islam menjunjung nilai-nilai pluralitas yang sejalan dengan keuniversalannya. Melalui nilai toleransi (tasamuh) yang terkandung dalam doktrin ajaran Islam, maka semakin membuktikan bahwa agama Islam relevan pada setiap tempat, zaman dan umat manusia.

Implementasi nilai toleransi di MIN I Kota Malang tercermin dalam prilaku, aktivitas, dan interaksi saling menghargai yang terbangun dalam kehidupan warga madrasah. Bahkah sikap ini mampu berkembang pada

\footnotetext{
${ }^{6}$ Zuriah, Pendidikan Moral \& Budi Pekerti dalam Perspektif Perubahan. (Jakarta: Bumi Aksara, 2007), 71.

7 Zuhairi Misrawi, Membumikan Toleransi al-Quran; Inklusivisme, Pluralisme dan Multikulturalisme, (Jakarta: Moslem Moderate Society. 2010), 1
} 
lingkup yang lebih luas yakni melalui interaksi antar madrasah dan masyarakat. Diantaranya kerap kali MIN I Kota Malang mengadakan even yang melibatkan sekolah dan madrasah dari luar. Pernah juga mengadakan acara gerak jalan sehat yang bertemakan kerukunan umat beragama yang melibatkan peserta dari sekolah lintas agama.

4) Kesetaraan dan Keadilan

Nilai kesetaraan, memandang manusia memiliki derajad yang sama. (lihat. QS. Al- Ankabut: 46)

"Dan janganlah kamu berdebat dengan Ahli Kitab, melainkan dengan cara yang paling baik, kecuali dengan orang-orang zalim di antara mereka, dan katakanlah: "Kami telah beriman kepada (kitab-kitab) yang diturunkan kepada kami dan yang diturunkan kepadamu; Tuhan kami dan Tuhanmu adalah satu; dan kami hanya kepada-Nya berserah diri (QS. AlAnkabut:46)

Ayat tersebut, menggambarkan adannya nilai egaliter/kesetaraan. Di MIN I Kota Malang implementasi nilai kesetaraan tercermin dari adanya kesempatan yang sama bagi seluruh siswa memperoleh hak-haknya untuk berperan dan berpartisipasi dalam kegiatan pendidikan tanpa ada diskriminasi, dan marginalisasi apapun sukunya, etnisnya, bahasa, kulit, faham, gender dan perbedaan-perbedaan lain yang melekat pada diri siswa. Sementara nilai keadilan diambil dari kata ' adl yang mempunyai arti 'sama dan seimbang'. Konsep keadilan menurut Yulia Riswanti ${ }^{8}$ berarti pengakuan dan perlakuan yang sama antara hak dan kewajiban. Dengan kata lain keadilan dapat juga diartikan sebagai keseimbangan atau keharmonisan antara menuntut hak, dan menjalankan kewajiban.

Islam mengajarkan nilai-nilai keadilan. Semua orang tanpa memandang perbedaan jenis kelamin, warna kulit, status ekonomi, maupun sosial mendapat perlakuan yang sama dan sederajat dalam baik dalam hukum, politik, dan agama. Karena itu Allah sangat menyukai orang yang bersikap adil "muqsithin" sebaliknya ketidakadilan akan membawa kepada kesenjangan dan kecemburuan (lihat (QS. Al-Maidah[5]:42).

Indikator tumbuh dan berkembangnya nilai kesetaraan dan keadilan di MIN I Kota Malang dibuktikan dengan adanya fasilitas pembelajaran yang memadai, sarana, prasarana, serta wadah pengembangan diri melalui kegiatan ekstrakurikuler yang berjumlah 26 pilihan yang diberikan sama

\footnotetext{
${ }^{8}$ Yulia Riswanti,. Urgensi Pendidikan Islam dalam Membangun Multikulturalisme. Jurnal Pendidikan Islam. Vol.3. No.2, 2008, 31.
} 
kepada peserta didik tanpa adanya diskriminasi. Semua diperlakukan setara dan seimbang.

5) Humanis

Implementasi nilai humanis dalam praktek pendidikan multikultural di MIN I Kota Malang selaras dilakukan dengan menghormati harkat dan martabat manusia. Pernyataan ini tercermin dari kebijakan madrasah untuk mencapai pada tujuan pembelajaran yang disesuaikan dengan kebutuhan peserta didik baik jasmani, rohani maupun psikologisnya. Selain melalui kebijakan, implementasi nilai humanis juga tampak jelas dari adanya proses pembelajaran yang menghargai harkat dan martabat manusia, yakni, didasarkan pada pengembangan seluruh potensi dan dilaksanakan dalam hubungan kesalingan (saling menerima, menghargai, terbuka, hangat, dengan menggunakan pendekatan multistrategi dan multimedia, memanfaatkan lingkungan, serta mendayagunakan kondisi alam, sosial dan budaya serta kekayaan daerah.

Realitas tersebut, memiliki relevansi dengan pendapat tokoh psikologi humanis Abraham Maslow yang berpandangan bahwa manusia memiliki potensi untuk maju dan berkembang. Melalui teori kebutuhan yang Ia kemukakan manusia memiliki kebutuhan dasar (basic needs) yang dibentuk menjadi 5 hirarki. Meliputi fisiologis, rasa aman, kasih sayang, harga diri dan mengekspresikan diri. $^{9}$ Hirarki kebutuhan tersebut berimplikasi pada implementasi pendidikan, diantaranya guru harus memperhatikan kebutuhan siswa ketika sedang beraktivitas di kelas, guru memahami karakteristik masing-masing peserta didiknya, termasuk membuat sebuah rekayasa pembelajaran yang mampu memberikan rasa aman, menyenangkan dan mengembangkan seluruh potensi yang dimililiki siswanya dari berbagai latar belakang kemampuan, usia, etnis dan gender.

Oleh karenanya, dalam pendidikan Islam multikultural disyaratkan bagi guru untuk berkemampuan memahami bakat, tabiat dan watak peserta didiknya. Artinya guru harus memiliki pengetahuan dan keterampilan psikologi, agar mampu memahami tabiat, perkembangan dan pertumbuhan peserta didiknya sebagai landasan dasar pengembangan potensi mereka (AlAbrasyi, 1980). ${ }^{10}$ Guru juga harus mampu menjadi figur orang tua yang memiliki kasih sayang dan mencintai murid-muridnya seperti cintanya kepada anaknya sendiri. Karena dengan kasih sayang dan cinta yang

\footnotetext{
${ }^{9}$ Maslow, Motivation and Personality. Jakarta: Rajawali. 2010), 49.

${ }^{10}$ Ahmad Syar'i, Filsafat Pendidikan Islam. (Jakarta: Pustaka Firdaus, 2005), 37.
} 
diberikan guru seorang murid akan mematuhi dan menerima ajaran yang diberikan. ${ }^{11}$

6) Tolong Menolong

Tolong menolong merupakan salah satu karakter sosial yang terpuji secara universal. ${ }^{12}$ Dalam Islam nilai ini disamakan dengan konsep ta'awun sebagaimana dalam QS. Al. Maidah Ayat 2.

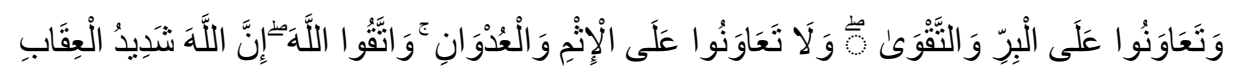

Artinya: "Dan tolong-menolonglah kamu dalam (mengerjakan) kebajikan dan takwa, dan jangan tolong-menolong dalam berbuat dosa dan pelanggaran. Dan bertakwalah kamu kepada Allah, sesungguhnya Allah amat berat siksa-Nya." (QS.al-Mâidah[5]:2).

Secara eksplisit ayat di atas, menegaskan bahwa setiap individu mempunyai kewajiban saling tolong menolong yakni melalui kata atta'awun. Inilah landasan etik dalam membina hubungan sosial dalam masyarakat yang plural. Nilai tolong menolong di MIN I Kota Malang tercermin dari interaksi saling peduli terhadap orang lain. Melalui prinsip "tomat" tolong menolong dan meminta maaf ini dapat membentuk pembiasaan budaya tolong menolong dan saling membantu melalui aktivitas paling sederhana dimulai dari menolong diri sendiri dan orang lain. Menolong diri sendiri seperti terbiasa memakai baju sendiri, sepatu sendiri membawa dan menyiapkan peralatan sekolah sendiri yang dilakukan baik di rumah maupun di sekolah.

7) Nilai Kebangsaan

Indonesia adalah negara yang memiliki keragaman budaya cukup tinggi. Dalam konteks ini membutuhkan adanya kekuatan yang menyatukan (integrating force) seluruh keragaman/pluraritas tersebut. Oleh karenanya, pendidikan mempunyai peran penting untuk membangun keutuhan bangsa (nasionalisme). Sebab itulah penanaman nilai kebangsaan merupakah hal yang mutlak. UU Sistem Pendidikan Nasional RI No. 20 tahun 2003 pasal 339, menjelaskan bahwa tujuan pendidikan Indonesia mengarahkan warganya kepada kehidupan yang beragam. Gagasan integrasi (nilai-nilai kebangsaan dan cinta tanah air) merupakan sebuah kebutuhan mendesak

\footnotetext{
${ }^{11}$ Abbudin Nata, Filsafat Pendidikan Islam, (Jakarta: Gaya Media Pratama, 2005), 127.

12 Abdul Wahid (ed), Hasan, Muhammad Tholhah, Pendidikan Multikultural (sebagai opsi penanggulangan radikalisme). (Malang: UNISMA, 2016), 68
} 
yang harus dijalankan. Pentingnya integrasi pendidikan nilai tersebut menjadi satu kerangka normatif dalam merumuskan tujuan pendidikan Islam sebagaimana diungkapkan Asraf dalam Muhaimin, bahwa tujuan pendidikan Islam membekali anak didik dengan berbagai kemampuan pengetahuan dan kebajikan, baik pengetahuan praktis, kesejahteraan, lingkungan sosial, dan pembangunan nasional. ${ }^{13}$

8) Nilai Kebersamaan

Secara Doktrinal, Islam banyak mengajarkan perintah untuk membangun kebersamaan. Diantaranya telah disebutkan dalam (QS. Ali 'Imran [3]: 103).

Artinya: "Dan berpegang teguhlah kamu sekalian dengan tali Allah dan janganlah kamu sekalian berpecah belah, dan ingatlah nikmat Allah atas kaти sетиa ketika kaтu bermusuh-musuhan maka Dia (Allah) menjinakkan antara hati-hati kamu maka kamu menjadi bersaudara sedangkan kamu diatas tepi jurang api neraka, maka Allah mendamaikan antara hati kamu. Demikianlah Allah menjelaskan ayat ayatnya agar kamu mendapat petunjuk” QS. Ali 'Imran [3]: 103).

Nilai-nilai kebersamaan memiliki peran yang kuat dalam mengembangkan kualitas dan kemajuan madrasah. Melalui kebersamaan, persaudaraan dan kerjasama akan muncul ikatan yang kuat sehingga menjadi kekuatan untuk mengembangkan organisasi. Implementasi nilai kebersamaan nampak dari adanya semangat kebersamaan dan dukungan warga madrasah dalam setiap kegiatan, program atau event madrasah. Dalah konteks ini, tak hanya guru dan siswa, tetapi orang tua juga mampu mengambil peran untuk bersama-sama menyukseskan berbagai kegiatan madrasah melalui keterlibatan langsung dalam event-event tertentu, Paguyupan Orang Tua (POS) dan komite. Melalui kebersamaan ragam prestasi dapat diraih, melalui kebersamaan pula rasa persaudaraan terbangun.

9) Nilai Kekeluargaan

Nilai kekeluargaan merupakan salah satu nilai yang menjadi basis hubungan warga MIN I Kota Malang dalam kondisi yang plural. Melalui dimensi hubungan sosial ini setiap individu dapat saling melengkapi dan menguatkan terhadap yang lain. ${ }^{14}$

\footnotetext{
${ }^{13}$ Muhaimin, Nuansa Baru Pendidikan Islam. (Jakarta: PT. Grafindo Persada, 2006), 136-138.

${ }^{14}$ Robbayani, Urgensi Pendidikan Agama Islam dalam Keluarga. Jurnal: Ilmu Tarbiyah "At-tajdid” vol. 1. No 1, 2012, 100. 
Dengan kekeluargaan timbul semangat kerjasama, rasa menghormati kepada yang lebih tua, dan menyayangi yang lebih muda. Islam memberi perhatian terhadap nilai kekeluargaan sebagaimana dalam bentuk perhatian, kepedulian, hubungan yang akrab, dan merasa seperjuangan. Muhaimin ${ }^{15}$ menyatakan dengan kekeluargaan maka terciptalah ukhuwah fi ubudiyah, ukhuwah fi insaniyah, ukhuwah fi wathaniyah dan ukhuwah fi din al-Islam.

10) Kesalehan Sosial

Sebagai mahluk sosial manusia tidak dapat jauh dari manusia lainnya karena tidak dapat lepas dari hubungan yang satu dengan hubungan yang lainnya. Nilai kealehan sosial di MIN I Kota Malang tercermin dari kepedulian warga madarsah terhadap lingkungan sekitarnya. Yakni peduli sosial. Implementasi nilai kesalehan sosial, diwujudkan melalui sikap kepeduian. Yakni peduli lingkungan dan sesama yang diwujudkan dalam bentuk kegiatan bhakti sosial, beramal, menjaga kebersihan menjaga lingkungan dan sebagainya. Melalui sikap tersebut, maka relevan dengan visi misi pendidikan Islam, yakni membentuk kesalehan pribadi sekaligus kesalehan sosial. Sehingga pendidikan agama tidak menimbulkan sikap fanatik, intoleran, serta memperlemah kerukunan hidup bersama, persatuan dan kesatuan nasional.

11) Penghargaan terhadap Prestasi

Penghargaan merupakan bentuk apresiasi terhadap pelaku kebaikan siapapun itu. Pendidikan Islam menggunakan "penghargaan" sebagai bagian dalam proses pembelajaran dalam mencapai tujuan. Sebut saja teori reword/penghargaan atas prilaku baik yang ditunjukkan siswa. Di dalam alQur'an banyak sekali contoh ayat-ayat yang menunjukkankan apresiasi terhadap prestasi (lihat.QS. Al Bayyinah ayat 8).

Dengan penghargaan terhadap prestasi, mensyaratkan bagi seluruh sivitas akademika MIN I Kota Malang untuk berupaya dengan maksimal dalam mengembangkan potensi dan kompetensi yang dimiliki. Dalam pandangan psikologi, hadiah/penghargaan membantu anak untuk belajar, sebab ketika memberi hadiah kita membantu mereka untuk berbuat baik, teori belajar juga menekankan bahwa berbagai penghargaan dapat menimbulkan respon positif pada anak dan dapat menciptakan kebiasaan yang relatif kokoh dalam dirinya. ${ }^{16}$ Sehingga dengan penghargaan terhadap prestasi diharapkan dapat mengembangkan seluruh potensi yang dimiliki

\footnotetext{
${ }^{15}$ Muhaimin, Paradigma pendidikan Islam (upaya mengefektifkan pendidikan agama di sekolah). (Bandung: Remaja Rosdakarya, 2008), 76,

${ }^{16}$ Ahmad Budaiwi, 2002. Imbalan dan Hukuman Pengaruhnya Bagi Pendidikan Anak, (Jakarta: Gema Insani Press, 2002), 40.
} 
warga MIN I Kota Malang. Hal ini merupakan salah satu wujud apresiasi terhadap implementasi pendidikan multikultural.

\section{Proses Pembelajaran Nilai dan Sikap Multikultural di MIN I Kota Malang}

Berdasarkan deskripsi kegiatan proses pembelajaran di MIN I Kota Malang, ditemukan bahwa proses pembelajaran nilai dan sikap multikultural di MIN I Kota Malang didasarkan pada nilai-nilai Islam multikultural. Adapun proses pembelajaran tersebut dilakukan melalui pemberdayaan budaya madrasah dan psikis-sosial di MIN I Kota Malang yang dilakukan dilakukan melalui budaya beriman/relegius, budaya akhlak mulia dan budaya berprestasi yang terejawantahkan dalam kegiatan pembiasaan atau habituasi berikut ini:

1) Pembelajaran melalui budaya relegius meliputi:

a) Pembiasaan gemar membaca Al-Qur'an

b) PPKM (program pengembangan keagamaan dan akhlak mulia)

c) Pembiasaan shalat dhuha dan dhuhur berjamaah

d) Pembiasaan amal ibadah sunnah

2) Pembelajaran melalui budaya akhlak mulia meliputi:

a) Tradisi $5 \mathrm{~S}$ (senyum, sapa, salam, salim, dan santun)

b) Tolong menolong

c) Suka memberi dan meminta maaf

d) Permisi dan terima kasih

3) Pembelajaran melalui budaya berprestasi meliputi:

a) Prestasi akhlak mulia

b) Prestasi agama dan keagamaan

c) Prestasi sains dan tehnologi

d) Prestasi olah raga dan seni

e) Prestasi budaya dan bahasa

Yang selanjutnya dari ketiga budaya tersebut, tumbuhlah budaya toleransi terhadap perbedaan keragaman budaya di MIN I Kota Malang. Sehingga dengan adanya toleransi berkembanglah nilai-nilai keimanan, keramahan dan sopan santun, kesetaraan, keadilan, keteladanan, tolong menolong, Kebangsaan, Kebersamaan, kekeluargaan dan penghargaan terhadap prestasi. Yang pada ahirnya mampu memberikan pemahaman serta menjadikan warga MIN I Kota Malang sebagai muslim muslimat yang moderat yang memiliki kesalehan sosial dalam ketaatan ritual sebagaimana visinya menjadikan beriman dan berakhlak mulia dan berprestasi. 
Zamroni ${ }^{17}$ mendefinisikan kultur sekolah/madrasah sebagai aspek sekolah atau madrasah yang sosial non fisik yang terjadi dan diciptakan oleh sistem keyakinan dan sistem nilai-nilai yang aa di kelompok warga sekolah itu sendiri. Kultur sekolah pada prakteknya, mencakup aspek-aspek bagaimana pengaturan jadwal sekolah, kurikulum pada tingkat satuan pendidikan, kondisi demografi warga sekolah, kebijakan dan bagaimana interaksi warga sekolah sehingga menimbulkan kesan sekolah sangat bersahabat, angkuh dan sebagainya. Oleh karenanya kultur ini sangat penting. Karena dari kultur inilah yang akan menentukan bagaimana pedagogi diaplikasikan, bagaimana assesment dilakukan, bagaimana komunikasi diantara sekolah, siswa dan orang tua dikembangkan, dan bagaimana hubungan diantara para guru dilaksanakan.

Selain ketiga budaya tersebut MIN I Kota Malang juga membiasakan berjiwa nasionalis yang dilakukan melalui pembiasaan membaca pancasila setiap sebelum memulai pembelajaran, menyanyikan lagu kebangsaan Indonesia raya yang merupakan pembiasaan untuk mengenalkan dan mengajarkan nilai-nilai kebangsaan kepada peserta didik, disamping kegiatan rutin pada hari senin yakni upaca bendera, peringatan hari besar nasional, menyelenggarakan "proyek budaya" melalui kegiatan puncak tema untuk mengenalkan dan mensosialisasikan simbol-simbol identitas nasional, seperti rumah adat, pakaian adat, musik dan makanan tradisional, lagu kebangsaan, dan gelar prestasi yang menjadi agenda wajib tiap tahunnya, termasuk atribut kenegaraan seperti bendera Merah Putih, Lambang negara Garuda Pancasila.

Dengan mengajarkan budaya lokal untuk bangga terhadap budaya Indonesia relevan dengan pandangan Tilaar, bahwa dimensi pendidikan multikultural di Indonesia yang pertama adalah righ to culture dan identitas budaya lokal. ${ }^{18}$

Melalui pembelajaran budaya tersebut, bukan hanya memperhatikan pemahaman terhadap ajaran dan nilai-nilai multikultural, tetapi juga memperhatikan dan mementingkan aspek penghayatan dan aktualisasi terhadap subtansi nilai-nilai pendidikan Islam multikultural. Hal ini relevan dengan isi standar proses tentang pembelajaran pengembangan sikap nilai (pembelajaran tidak langsung) sebagai jabaran. ${ }^{19}$

${ }^{17}$ Zamroni, Kultur Sekolah. (Yogyakarta: Gavin Kalam Utama, 2016), 62.

${ }^{18}$ H.A.R. Tilaar, Multikulturalisme, Tantangan-Tantangan Global Masa Depan dalam Transformasi Pendidikan Nasional, (Jakarta: Grasindo, 2004), 185-190.

${ }^{19}$ KMA No 165 tahun 2016 tentang Kurikulum Madrasah Ibtidaiyah, (Malang: MIN) 286. 
Hal ini didukung oleh pernyataan Smith bahwa dalam proses pembelajaran nilai multikultural di sekolah harus dikondisikan sebagai tempat interaksi sosial dari seluruh elemen yang beragam secara educative demokratis. Sehingga menuntut perubahana kondisi lingkungan pendidikan yang terkonstruksi dengan setting yang dinamis, agar proses komunikasi dan interaksi edukatif dari seluruh elemen yang beragam dapat berlangsung efektif. ${ }^{20}$

Disinilah peran pemberdayaan terhadap lingkungan psikis dan sosial diperlukan. Antara lain pengelolaan terhadap prilaku dan interaksi yang terbangun di dalamnya, termasuk menunjukkan suasana yang hangat, nyaman, positif, kompetitif, dan disiplin.

\section{PENUTUP}

Berdasarkan hasil paparan di atas, maka nilai pendidikan Islam multikultural yang tumbuh dalam budaya MIN I Kota Malang terejawantahkan dalam 12 nilai. Diantara nilai tersebut adalah: 1) nilai keberagamaan berupa keimanan terhadap Tuhan Yang Maha Esa, 2) keramahan dan sopan santun, 3) toleransi, 4) kesetaraan, 5) keadilan, 6) humanis, 7) tolong menolong, 8) kebangsaan, 9) kebersamaan, 10) kekeluargaan, 11) kesalehan sosial, dan 12) penghargaan terhadap prestasi. Sedangkan pembelajaran nilai dan sikap multikultural di MIN I Kota Malang diimplementasikan melalui; pengelolaan kondisi ekologi (material culture) meliputi lingkungan fisik (kondisi bangunan gedung, sarana prasarana serta tata ruang madrasah), dan pola interaksi warga madrasah dalam struktur madrasah (behaviour culture) yang tercermin dari budaya relegius, budaya akhlak mulia, budaya berprestasi dan budaya nasionalis.

\section{DAFTAR PUSTAKA}

Abdul Wahid (ed), Muhammad Tholhah Hasan, 2016. Pendidikan Multikultural (sebagai opsi penanggulangan radikalisme). Malang: UNISMA.

Abbudin Nata, 2005. Filsafat Pendidikan Islam .Jakarta: Gaya Media Pratama.

Al-Qur'an Terjemah. 2010. TIM Departemen Agama RI.

${ }^{20}$ Matrk Smith, Curriculum Theory and Practice. (London: Routledge. 2002), 6. 
Ahmad Budaiwi, 2002. Imbalan dan Hukuman Pengaruhnya Bagi Pendidikan Anak, Jakarta: Gema Insani Press.

Ahmad Syar'i, 2005. Filsafat Pendidikan Islam. Jakarta: Pustaka Firdaus.

H.A.R. Tilaar, 2004. Multikulturalisme, Tantangan-Tantangan Global Masa Depan dalam Transformasi Pendidikan Nasional, Jakarta: Grasindo.

KMA No 165 tahun 2016 tentang Kurikulum Madrasah Ibtidaiyah.

Maslow, 2010. Motivation and Personality. Jakarta: Rajawali.

Matrk Smith, 2002. Curriculum Theory and Practice. London: Routledge.

Muhaimin, 2006. Nuansa Baru Pendidikan Islam. Jakarta: PT. Grafindo Persada.

, 2008. Paradigma pendidikan Islam (upaya mengefektifkan pendidikan agama di sekolah). Bandung: Remaja Rosdakarya

Ngainun Naim dan Ahmad Syauqi, 2008. Pendidikan Multikultural: Konsep dan Aplikasi Jogjakarta: Ar-Ruzz Media.

Sugiono, 2011. Metode Penelitian Kuantitatif Kualitatif dan $R \& D$, Bandung: Alfabeta.

W. John Creswell, 2015. Penelitian Kualitatif dan Desain Riset: Memilih diantara Lima Pendekatan, Yogyakarta. Pustaka Pelajar

Zamroni, 2016. Kultur Sekolah. Yogyakarta: Gavin Kalam Utama

Zuhairi Misrawi, 2010. Membumikan Toleransi al-Quran; Inklusivisme, Pluralisme dan Multikulturalisme, Jakarta: Moslem Moderate Society.

Zuriah, 2007. Pendidikan Moral \& Budi Pekerti dalam Perspektif Perubahan. Jakarta: Bumi Aksara.

Hujair AH Sanaky, 2014. Mengembangkan Model Ideal Pendidikan Islami. EL-TARBAWI VOL. 7 NO.1.

Robbayani, 2012. Urgensi Pendidikan Agama Islam dalam Keluarga. Jurnal: Ilmu Tarbiyah "At-tajdid" vol. 1. No 1

Yulia Riswanti,. 2008. Urgensi Pendidikan Islam dalam Membangun Multikulturalisme. Jurnal Pendidikan Islam. Vol.3. No.2

UU Sistem Pendidikan Nasional RI No. 20 tahun 2003 
PEMBELAJARAN NILAI MULTIKULTURAL DALAM BUDAYA MADRASAH DI MIN I KOTA MALANG (Fita Mustafida) 